\title{
FORMULASI LEGISLASI PERLINDUNGAN DATA PRIBADI DALAM REVOLUSI INDUSTRI 4.0
}

\author{
(The Legislation Formulation of Personal Data Protection In The Industrial Revolution Era 4.0)
}

\author{
Erlina Maria Christin Sinaga \\ Pusat Penelitian dan Pengkajian Perkara, dan Pengelolaan Perpustakaan \\ Mahkamah Konstitusi Republik Indonesia \\ Jalan Medan Merdeka Barat Nomor 6, Jakarta Pusat \\ e-mail: erlina.maria@mkri.id \\ Mery Christian Putri \\ Pusat Penelitian dan Pengkajian Perkara, dan Pengelolaan Perpustakaan \\ Mahkamah Konstitusi Republik Indonesia \\ Jalan Medan Merdeka Barat Nomor 6, Jakarta Pusat \\ e-mail: mery_christian@mkri.id
}

Naskah diterima: 20 April 2020; revisi: 9 Juli 2020; disetujui: 9 Juli 2020

\begin{abstract}
Abstrak
Era revolusi industri 4.0 berdampak dalam transformasi proses bisnis yang mendorong inovasi dan efisiensi. Pertumbuhan pengguna internet yang signifikan dalam pasar digital di berbagai bidang seperti perdagangan, pendidikan, kesehatan, pemerintahan, dan komunikasi memicu problematika dalam aspek perlindungan data pribadi warga negara. Konstitusi telah memberikan perlindungan data pribadi yang dioperasionalkan dalam beberapa Undang-Undang di berbagai aspek. Penelitian ini akan mengkaji peraturan perlindungan pribadi di Indonesia yang masih diatur secara parsial dalam berbagai perundangan serta menjawab bagaimana kesiapan Indonesia dan urgensi pengaturan regulasi perlidungan data pribadi serta memaparkan perbadingan regulasi perlindungan data pribadi di Uni Eropa berdasarkan General Data Protection Regulation. Metode penelitian adalah yuridis normatif dengan pendekatan kepustakaan yang menganalisis data sekunder berupa bahan hukum primer dan bahan hukum sekunder. Hasil dari penelitian ini adalah legislator perlu menyegerakan pengesahan Undang-Undang perlindungan data pribadi dengan melengkapi norma yang telah disusun dalam RUU yaitu terkait pembentukan lembaga yang berfungsi sebagai pengawas, regulator, dan pengendali (independent regulatory body) atau komisi pengawas perlindungan data pribadi.
\end{abstract}

Kata Kunci: perlindungan data pribadi, revolusi industri 4.0, GDPR.

\begin{abstract}
The industrial revolution era 4.0 has implied in the transformation of business process which support inovation and eficiency. The significant growth number of internet user in a digital market from various sectors that is e-commerce, e-education, e-health, e-government, and communication triggers problematic issue in the aspect of citizens' personal data protection. 1945 Constitution has stipulated the personal data protection norms which is nationalized in many regulations from many aspects. This research will analize the personal data protection regulation in Indonesia that is partially regulated and answer how Indonesia is prepared and the urgency of regulation personal data protection and describe the comparative of personal data protection in European Union based on General Data Protection Regulation. The methode of this research is normative juridical with library and statute approach which will analize secondary data consisting of primary source of law and secondary source of law. This research results a conclusion that the legislator needs to hasten the ratification of the Law on the personal data protection by completing the norms that have been prepared in the Draft Bill, which is related to the establishment of institutions that function as supervisors, regulators, and controller (independent regulatory body or the supervisory committee for personal data protection.
\end{abstract}

Keywords: personal data protection, industrial revolution 4.0, GDPR. 


\section{A. Pendahuluan}

Revolusi industri 4.0 merupakan disruption era yaitu era disrupsi dimana cara kerja berpindah atau berubah dari cara kerja yang konvensional menjadi moderen, dengan pendekatan digital. Oleh sebab itu, semua lapisan harus dapat bersahabat dengan yang namanya teknologi supaya dapat mengikuti perkembangan jaman yang semakin maju. Indonesia sebagai negara yang berkembang telah memasukiera ekonomi digital dan industri 4.0 yang ditandai dengan meningkatnya data jumlah pengguna internet. ${ }^{1}$ Dari total populasi 262 juta jiwa, tercatat memiliki 140 juta warganya menggunakan internet dalam aktivitas sehari-hari dan setidaknya 28 (dua puluh delapan) juta masyarakat Indonesia sangat aktif melakukan transaksi online. ${ }^{2}$

Pertumbuhan pengguna internet juga diiringi dengan munculnya perusahaan teknologi yang memberikan dampak yang signifikan dalam transformasi proses bisnis yang mendorong inovasi dan efisiensi. Oleh karenanya kita juga harus mampu mengikuti ritme perkembangan teknologi. Hal ini terlihat dengan Pemerintah Indonesia sedang menyusun perencanaan 'Making Indonesia 4.0'. Upaya ini dilakukan untuk mempercepat terwujudnya visi nasional dan peluang menghadapi era revolusi industri 4.0 termasuk dengan aspek hukum yang akan menjadi tantangan dan hambatan pemerintah dalam menerapkan Making Indonesia 4.0, seperti masalah hukum atau regulasi, masalah penegakan hukum dan kesiapan masyarakat atau sumber daya manusia di Indonesia.

Tujuan bernegara dalam perkembangan teknologi informasi dan komunikasi diwujudkan dalam bentuk perlindungan data pribadi bagi semua warga negara Indonesia. Sebagai negara yang berkembang dilihat dengan adanya inovasi dalam teknologi informasi dan komunikasi yang dapat mengumpulkan, menyimpan, serta menganalisis data. Hal ini membuat berbagai sektor kehidupan akan selalu memanfaatkan sistem teknologi informasi dan komunikasi, misalnya dalam hal electronic commerce (e-commerce) pada sektor perdagangan/ bisnis, electronic education (e-education) di bidang pendidikan, electronic health (e-health) di bidang kesehatan, electronic government (e-government) pada bidang pemerintahan, search engines, social networks, smartphone dan mobile internet serta perkembangan industri komputasi awan atau cloud computing. ${ }^{3}$

Problematika tentang pentingnya perlindungan data pribadi mulai menguat seiring dengan meningkatnya jumlah pengguna telepon seluler dan internet. Banyak kasus terjadi yang berkaitan dengan kasus penyalahgunaan dan kejahatan data pribadi seperti jual beli data pribadi, penggelapan rekening nasabah, kebocoran data pribadi seseorang yang berakhir dengan aksi penipuan atau tindak kriminal pornografi. Berkaca dari kejadian ini semakin 
menguatkan wacana pentingnya pembuatan aturan hukum untuk melindungi data pribadi. Perlindungan data pribadi berhubungan dengan konsep privasi. Konsep privasi sendiri adalah gagasan untuk menjaga integritas dan martabat pribadi. Hak privasi juga merupakan kemampuan individu untuk menentukan siapa yang memegang informasi tentang mereka dan bagaimana informasi tersebut digunakan. ${ }^{4}$ Dalam beberapa tahun terakhir secara global telah terjadi banyak kasus kebocoran data pribadi yang berimbas kepada Indonesia contohnya kasus Yahoo tahun 2014 ketika dalam proses penjualan kepemilikan pada Verizon menyatakan telah mengalami kebocoran 500 juta data pelanggan dan Yahoo menderita kerugian dengan menurunnya aset penjualan hingga 350 juta dolar. ${ }^{5}$

Dalam amandemen keempat UndangUndang Dasar Negara Republik Indonesia Tahun 1945, diatur mengenai hak asasi manusia sebagai wujud jaminan atas perlindungan hak-hak warga negara. Hal ini juga sejalan dengan Undang-Undang Nomor 39 Tahun 1999 tentang Hak Asasi Manusia yang beberapa pasal diantaranya menjamin perlindungan hak atas privasi warga negara: ${ }^{6}$

a) Pasal 14 ayat (2) menyatakan bahwa, Setiap orang berhak untuk mencari, memperoleh, memiliki, menyimpan, mengolah, dan menyampaikan informasi dengan menggunakan segala jenis sarana yang tersedia.

b) Pasal 29 ayat (1) menyatakan bahwa, Setiap orang berhak atas perlindungan diri pribadi, keluarga, kehormatan, martabat, dan hak miliknya.

c) Pasal 31 menyatakan bahwa, (1) Tempat kejadian siapapun tidak boleh diganggu. (2) Menginjak atau memasuki suatu pekarangan tempat kediaman atau memasuki suatu rumah bertentangan dengan kehendak orang yang mendiaminya, hanya diperbolehkan dalam hal-hal yang telah ditetapkan oleh undang-undang.

Bagi perkembangan ekonomi, perlindungan data pribadi yang bersifat khusus akan memperkuat posisi Indonesia sebagai pusat bisnis dan investasi terpercaya dan menciptakan lingkungan yang kondusif untuk pertumbuhan manajemen data global dan industri pengolahan data seperti komputasi awan untuk berkembang di Indonesia. Ketiadaan hukum mengenai perlindungan data pribadi yang bersifat umum di Indonesia dapat dilihat sebagai suatu kelemahan yang menyebabkan beberapa perusahaan tidak memilih Indonesia sebagai lokasi untuk pusat penyimpanan datanya. Padahal, perkembangan pengaturan perlindungan data pribadi akan mendukung pembangunan masa depan Indonesia sebagai pusat data global. Pengaturan tentang data pribadi sangat diperlukan karena mengatur mengenai pengumpulan, penggunaan, pengungkapan, pengiriman dan keamanan data pribadi dan secara umum pengaturan data pribadi adalah untuk mencari keseimbangan antara

4 Wahyudi Djafar dan Asep Komarudin, Perlindungan Hak Atas Privasi di Internet-Beberapa Penjelasan Kunci, Elsam, Jakarta, 2014, hlm. 2.

5 https://www.csoonline.com/article/2130877/data-breach/the-biggest-data-breaches-of-the-21stcentury. html.

$6 \quad$ Lihat Pasal 14 ayat (2), Pasal 29 ayat (1), Pasal 31 Undang-Undang Nomor 39 Tahun 1999 tentang Hak Asasi Manusia. 
kebutuhan akan perlindungan data pribadi individu dengan kebutuhan pemerintah dan pelaku bisnis untuk memperoleh dan memproses data pribadi untuk keperluan yang wajar dan sah.

Dengan mempertimbangkan semua ancaman dan potensi pelanggaran seperti yang Penulis sebutkan, maka Penulis akan mengkaji lebih lanjut mengenai pengaturan regulasi data pribadi dalam Undang-Undang Nomor 11 Tahun 2008 tentang Informasi dan Transaksi Elektronik, apakah regulasi yang ada dalam UU tersebut telah mampu memberikan kesiapan Indonesia dalam Revolusi Industri 4.0, serta bagaimana seharusnya Indonesia dalam menyiapkan regulasi khusus terkait perlindungan data pribadi.

\section{B. Metode Penelitian}

Penelitian ini merupakan penelitian terkait regulasi perlindungan data pribadi dalam menghadapi revolusi industri 4.0 dengan menggunakan metode yuridis normatif. Penulis melakukan studi kepustakaan (library research) dengan menganalisis data sekunder berupa bahan hukum primer dan bahan hukum sekunder. Bahan hukum primer meliputi Undang-Undang Dasar Negara Republik Indonesia Tahun 1945, Undang-Undang Nomor 11 Tahun 2008 tentang Informasi dan Transaksi Elektronik sebagaimana telah diubah dengan Undang-Undang Nomor 19 Tahun 2016 tentang Perubahan Atas UndangUndang Nomor 11 Tahun 2008 tentang Informasi dan Transaksi Elektronik serta berbagai peraturan perundang-undangan terkait lainnya. Penelitian ini dilaksanakan untuk memecahkan permasalahan hukum yang diajukan sehingga mendapatkan deskripsi hasil yang seyogianya. ${ }^{7}$

\section{Pembahasan}

\section{Pengaturan Regulasi Perlindungan Data Pribadi Dalam Undang-Undang Informasi dan Transaksi Elektronik}

Dalam pembukaan Undang-Undang Dasar 1945 alinea ke-4 disebutkan bahwa pemerintah mempunyai kewajiban konstitusional untuk melindungi segenap bangsa dan seluruh tumpah darah Indonesia, memajukan kesejahteraan umum, mencerdaskan kehidupan bangsa, serta ikut melaksanakan ketertiban dunia yang berdasarkan kemerdekaan, perdamaian abadi dan keadilan sosial. Sejalan dengan perkembangan teknologi informasi dan komunikasi di era yang serba digital sekarang, tujuan bernegara diwujudkan dalam bentuk perlindungan data pribadi bagi setiap warga negara. Perlindungan data pribadi sebagai hak konstitusional warga negara yang harus dipenuhi oleh pemerintah secara hirarkis peraturan perundang-undangan diturunkan ke dalam berbagai peraturan perundangundangan seperti halnya Undang-Undang HAM, Undang-Undang Keterbukaan Informasi Publik, Undang-Undang Intelijen Negara, Undang-Undang Administrasi Kependudukan, Undang-Undang Perbankan, Undang-Undang Perdagangan, Undang-Undang Informasi dan Transaksi Elektronik dan lain sebagainya.

Undang-Undang Informasi dan Transaksi Elektronik selanjutnya disebut UU ITE masih secara implisit mengatur pemahaman

Peter Mahmud Marzuki, Penelitian Hukum (Jakarta: Kencana, 2011), hlm. 89. 
mengenai perlindungan keberadaan suatu data atau informasi elektronik yang bersifat umum maupun pribadi. UU ITE belum memuat aturan tentang perlindungan data pribadi secara khusus. Perlindungan data pribadi dalam sebuah sistem elektronik dalam UU ITE meliputi perlindungan dari penggunaan tanpa izin, perlindungan oleh penyelenggara sistem elektronik, dan perlindungan dari akses dan interferensi ilegal. Sistem elektronik sebagai serangkaian perangkat dan prosedur elektronik yang berfungsi mempersiapkan, mengumpulkan, mengolah, menganalisis, menyimpan, menampilkan, mengumumkan, mengirimkan, dan/atau menyebarkan informasi elektronik. ${ }^{8}$ Jadi yang termasuk ke dalam sistem elektronik adalah jaringan internet, layanan e-banking, e-government, jejaring sosial, media elektronik, website, dan lain sebagainya.

Penjabaran tentang data elektronik
pribadi justru terdapat dalam Pemerintah Nomor 71 Tahun 2019 tentang Penyelenggaraan Sistem dan Transaksi Elektronik. Setiap data pribadi adalah setiap data tentang seseorang baik yang teridentifikasi dan/atau dapat diidentifikasi secara tersendiri atau dikombinasi dengan informasi lainnya baik secara langsung maupun tidak langsung melalui sistem elektronik dan/atau nonelektronik. ${ }^{9}$

Salah satu bentuk data yang dilindungi adalah yang berbentuk informasi elektronik sebagai sekumpulan data elektronik, termasuk tetapi tidak terbatas pada tulisan, suara, gambar, peta, rancangan, foto, electronic data interchange (EDI), surat elektronik (electronic mail), telegram, teleks, telecopy atau sejenisnya, huruf, tanda, angka, kode akses, simbol, atau perforasi. Informasi elektronik ini dapat terdapat dalam sistem elektronik atau berupa sebuah dokumen elektronik. ${ }^{10}$ Pelanggaran terhadap upaya perlindungan data pribadi tersebut, penyelenggara sistem elektronik akan diberikan sanksi administratif berupa teguran tertulis, denda administratif, penghentian sementara, serta dikeluarkan dari daftar penyelenggara sistem elektronik, agen elektronik, penyelenggara sertifikasi elektronik, atau lembaga sertifikasi keandalan. ${ }^{11}$

Dalam perlindungan data pribadi, UU ITE mensyaratkan bahwa penggunaan data pribadi dalam media elektronik harus mendapat persetujuan pemilik data bersangkutan dan bagi setiap orang yang melanggar ketentuan dapat digugat atas kerugian yang ditimbulkan. ${ }^{12}$ Dalam memanfaatkan

Pasal 1 angka 5 Undang-Undang Nomor 11 Tahun 2008 Tentang Informasi dan Transaksi Elektronik.

$9 \quad$ Pasal 1 ayat (29) Peraturan Pemerintah Nomor 71 Tahun 2019 tentang Penyelenggaraan Sistem dan Transaksi Elektronik.

10 Pasal 1 ayat (8) Peraturan Pemerintah Nomor 71 Tahun 2019 tentang Penyelenggaraan Sistem dan Transaksi Elektronik.

11 Pasal 100 Peraturan Pemerintah Nomor 71 Tahun 2019 tentang Penyelenggaraan Sistem dan Transaksi Elektronik.

12 Pasal 26 Undang-Undang Nomor 11 Tahun 2008 tentang Informasi dan Transaksi Elektronik.

(1) Kecuali ditentukan lain oleh Peraturan Perundang-undangan, penggunaan setiap informasi melalui media elektronik yang menyangkut data pribadi seseorang harus dilakukan atas persetujuan Orang yang bersangkutan;

(2) Setiap Orang yang dilanggar haknya sebagaimana dimaksud pada ayat (1) dapat mengajukan gugatan atas kerugian yang ditimbulkan berdasarkan Undang-Undang ini. 
teknologi informasi, perlindungan data pribadi adalah bagian dari hak privasi. Jadi seharusnya untuk memberikan rasa aman bagi pengguna sistem elektronik, dalam UU ITE diatur mengenai perlindungan atas data pribadi dan hak privasi yang tertuang dalam Pasal 26 ayat (1) UU ITE. Hak pribadi yang dimaksudkan diantaranya: ${ }^{13}$

a) hak pribadi merupakan hak untuk menikmati kehidupan pribadi dan bebas dari segala macam gangguan;

b) hak pribadi merupakan hak untuk dapat berkomunikasi dengan orang lain tanpa tindakan memata-matai;

c) hak pribadi merupakan hak untuk mengawasi akses informasi tentang kehidupan pribadi dan data seseorang.

Penggunaan setiap informasi dan data pribadi melalui media elektronik yang dilakukan tanpa persetujuan pemilik data disebut sebagai sebuah pelanggaran hak privasi. Meskipun terdapat pengakuan atas perlindungan hak privasi serta data pribadi dalam informasi dan transaksi elektronik dalam UU ITE sebagaimana terdapat dalam Pasal 26 beserta penjelasannya, upaya dan kewajiban perlindungan seharusnya dilakukan oleh pihak terkait seperti penyelenggara sistem elektronik ataupun pemerintah belum terdapat dalam UU ITE.

Perlindungan data pribadi oleh Penyelenggaraan Sistem Transaksi Elektronik yangmengaturbahwa dalam hal penyelenggara sistem elektronik mengalami kegagalan dalam menjaga data pribadi yang dikelola, maka Penyelenggaraan Sistem Transaksi
Elektronik diwajibkan untuk menyampaikan pemberitahuan tertulis kepada pemilik data pribadi. ${ }^{14}$ Penulis berpandangan bahwa pasal ini juga tidak secara rinci menjelaskan batasan kegagalan. Kegagalan dapat dikategorikan sebagai kegagalan prosedural ataupun juga kegagalan sistem. Dalam penjelasan Pasal 15 ayat (1) UU ITE disebutkan:

a) Andal yang berarti sistem elektronik memiliki kemampuan yang sesuai dengan kebutuhan penggunaannya;

b) Aman yang artinya sistem eletronik terlindungi secara fisik dan non fisik;

c) Beroperasi sebagaimana mestinya yang artinya sistem elektronik memiliki kemampuan sesuai dengan spesifikasinya.

Undang-Undang ITE memberikan perlindungan hukum terhadap keamanan data elektronik dari akses ilegal dikarenakan cracking yang mengakibatkan bocornya data yang bersifat rahasia maupun data pribadi. Setiap perbuatan melawan hukum dengan mengakses sistem elektronik yang bertujuan untuk memperoleh Informasi ataupun Dokumen Elektronik dengan cara melanggar sistem pengamanan dianggap sebagai tindak pidana dengan ancaman sanksi pidana penjara paling lama 6 sampai 8 tahun dan/atau denda paling banyak Rp. $600.000 .000,00$ sampai Rp. 800.000.000,00.

Dalam Pasal 30 UU ITE disebutkan bahwa:

(1) Setiap orang dengan sengaja dan tanpa hak atau melawan hukum mengakses komputer dan/atau Sistem Elektronik milik orang lain dengan cara apa pun. 
(2) Setiap orang dengan sengaja dan tanpa hak atau melawan hukum mengakses Komputer dan/atau Sistem Elektronik dengan cara apa pun dengan tujuan untuk memperoleh Informasi Elektronik dan/ atau Dokumen Elektronik;

(3) Setiap orang dengan sengaja dan tanpa hak atau melawan hukum mengakses Komputer dan/atau Sistem Elektronik dengan cara apa pun dengan melanggar, menerobos, melampaui, atau menjebol sistem pengamanan.

Kemudian dalam Pasal 46 UU ITE disebutkan bahwa:

(1) Setiap orang yang memenuhi unsur sebagaimana dimaksud dalam Pasal 30 ayat (1) dipidana dengan pidana penjara paling lama 6 (enam) tahun dan/atau denda paling banyak Rp. 600.000.000,00 (enam ratus juta rupiah).

(2) Setiap orang yang memenuhi unsur sebagaimana dimaksud dalam Pasal 30 ayat (2) dipidana dengan pidana penjara paling lama 7 (tujuh) tahun dan/atau denda paling banyak Rp. 700.000.000,00 (tujuh ratus juta rupiah).

(3) Setiap orang yang memenuhi unsur sebagaimana dimaksud dalam Pasal 30 ayat (3) dipidana dengan pidana penjara paling lama 8 (delapan) tahun dan/atau denda paling banyak Rp. 800.000.000,00 (delapan ratus juta rupiah).

Demikian juga halnya dengan perlindungan data pribadi dalam bentuk Dokumen Elektronik atau Informasi Elektronik. Dalam bentuk
Dokumen Elektronik atau Informasi Elektronik diatur mengenai larangan bagi setiap orang untuk melakukan interferensi, mengubah, menambah, mengurangi, melakukan transmisi, merusak, menghilangkan, memindahkan, menyembunyikan terhadap bentuk Dokumen Elektronik atau Informasi Elektronik tanpa hak dan dengan cara melawan hukum. ${ }^{15}$ Dengan ancaman hukuman atas perbuatan tersebut adalah pidana penjara dan juga pidana denda. ${ }^{16}$

Penulis berpandangan bahwa dari ulasan pasal-pasal dalam UU ITE tentang perlindungan data pribadi memang belum dapat mengakomodasi segala pelanggaran terhadap data pribadi. Kemajuan teknologi informasi dan komunikasi memang seolah membuat batas privasi semakin tipis. Berbagai data-data pribadi mudah tersebar. Tetapi belum ada payung hukum yang memadai mengatur soal perlindungan data pribadi di Indonesia. Seharusnya perlindungan data pribadi menjadi hal yang penting pada zaman digital karena semakin masifnya perkembangan penggunaan teknologi dalam kehidupan seharinya.

Dilndonesia, sekarang inidalam melindungi data pribadi pengguna internet memang masih menggunakan beberapa instrumen hukum yang masih berdiri masing-masing, seperti halnya Undang-Undang Hak Asasi Manusia, Undang-Undang Administrasi Kependudukan, Undang-Undang Kesehatan, Undang-Undang Perlindungan Konsumen, Undang-Undang Keterbukaan Informasi Publik, dan UndangUndang Telekomunikasi, Undang-Undang tentang Informasi dan Transaksi Elektronik

15 Pasal 32 Undang-Undang Nomor 19 Tahun 2016 Tentang Informasi dan Transaksi Elektronik.

16 Pasal 48 Undang-Undang Nomor 19 Tahun 2016 Tentang Informasi dan Transaksi Elektronik. 
(ITE), Peraturan Pemerintah Nomor 71 Tahun 2019 tentang Penyelenggaraan Sistem dan Transaksi Elektronik, Peraturan Menteri Komunikasi dan Informatika Nomor 20 Tahun 2016 tentang Perlindungan Data Pribadi dalam Sistem Elektronik, dan Peraturan Otoritas Jasa Keuangan (OJK) Nomor 77/POJK.01/2016 tentang Layanan Pinjam Meminjam Uang Berbasis Teknologi Informasi.

Namun peraturan perundang-undangan tersebutbelum mengatur secara komprehensif mengenai perlindungan data pribadi. Oleh karenanya, sangat perlu dibuat pengaturan perlindungan data pribadi dimaksudkan untuk melindungi kepentingan masyarakat. Terlebih di era revolusi Industri 4.0 sekarang ini harus dapat melindungi masyarakat sebagai konsumen dan memberikan manfaat ekonomi bagi Indonesia. Pengaturan ini akan melindungi data pribadi individu terhadap penyalahgunaan pada saat data tersebut memiliki nilai tinggi untuk kepentingan bisnis, yang pengumpulan serta pengolahannya menjadi mudah dengan perkembangan teknologi informasi komunikasi. Perkembangan pengaturan terhadap perlindungan data pribadi secara umum akan menempatkan Indonesia sejajar dengan negara-negara dengan tingkat perekonomian yang maju, yang telah menerapkan hukum mengenai perlindungan data pribadi. Hal ini akan memperkuat dan memperkokoh posisi Indonesia sebagai pusat bisnis dan investasi terpercaya, yang merupakan suatu strategi kunci dalam perkembangan ekonomi Indonesia.
Seharusnya dengan semakin pesatnya perkembangan teknologi dan meningkatnya jumlah pengguna layanan berbasis teknologi di Indonesia, upaya perlindungan data pribadi memerlukan payung hukum yang lebih kuat untuk memberikan jaminan terhadap hak masyarakat atas keamanan data pribadinya. Oleh karena itu, RUU Perlindungan Data Pribadi yang menjadi instrumen hukum perlu segera hadir dalam sistem hukum di Indonesia.

Secara filosofis, perlindungan data pribadi menjadi manifestasi pengakuan dan perlindungan atas hak-hak dasar manusia sesuai dengan nilai-nilai Pancasila. Secara sosiologis, RUU Perlindungan Data Pribadi disusun sebagai jawaban atas kebutuhan untuk melindungi hak individual terkait data pribadi khususnya di era digital. Secara yuridis, perlindungan data pribadi merupakan salah satu hak asasi manusia yang merupakan bagian dari perlindungan diri pribadi seperti yang telah diamanatkan dalam konstitusi yang menyatakan bahwa "Setiap orang berhak atas perlindungan diri pribadi, keluarga, kehormatan, martabat, dan harta benda yang di bawah kekuasaannya, serta berhak atas rasa aman dan perlindungan dari ancaman ketakutan untuk berbuat atau tidak berbuat sesuatu yang merupakan hak asasi". ${ }^{17}$ Selain itu disebutkan juga bahwa, "Setiap orang berhak mempunyai hak milik pribadi dan hak milik tersebut tidak boleh diambil alih secara sewenang-wenang oleh siapa pun". ${ }^{18}$

Tidak salah jika Penulis masih beranggapan bahwa ketentuan hukum terkait perlindungan data pribadi masih bersifat parsial dan sektoral 
dan belum bisa memberikan perlindungan yang optimal dan efektif terhadap data pribadi sebagai bagian dari privasi. Konsep perlindungan data memberikan isyarat bahwa individu memiliki hak untuk menentukan apakah mereka akan membagi atau bertukar data pribadi mereka atau tidak. Selain itu, individu juga memiliki hak untuk menentukan syarat-syarat pelaksanaan pemindahan data pribadi tersebut. Jadi perlindungan data juga berhubungan dengan konsep hak privasi.

\section{Kesiapan Indonesia dan Urgensi Regulasi Khusus Tentang Data Pribadi di Era Revolusi Industri 4.0}

Dalam era digital sekarang ini, Indonesia belum siap bersaing dalam dunia industri 4.0 dikarenakan belum memiliki peraturan perundang-undangan yang secara khusus mengatur mengenai perlindungan data pribadi sebab salah satu tujuan utama regulasi perlindungan data pribadi adalah melindungi kepentingan konsumen dan memberikan manfaat ekonomi bagi Indonesia.

\section{a. Perkembangan Hukum Perlindungan Data Pribadi di Negara Uni Eropa}

Digitalisasi yang memungkinkan adanya teknologi pemrosesan data moderen memiliki banyak keunggulan namun juga tidak lepas dari berbagai persoalan. Salah satu persoalan yang tanpa disadari telah banyak terjadi adalah ancaman terhadap hak individu atas privasi. Data pribadi yang dapat dikombinasikan dan disimpan secara unlimited dan dapat diakses secara luas memungkinkan pergerakan/persebaran data dan manipulasi informasi dalam berbagai bidang tanpa sepengetahuan pemilik data. Kebebasan individu juga dapat terancam dari adanya kemungkinan dari pemerintah dan pelaku usaha yang mengumpulkan informasi dari warga negara untuk tujuan tertentu. ${ }^{19}$

Willam L. Prosser menyebutkan ruang lingkup dari hak privasi sesorang dengan merujuk pada empat bentuk gangguan terhadap diri pribadi seseorang yaitu: ${ }^{20}$ a) Gangguan terhadap perilaku seseorang yang menyendiri atau gangguan terhadap relasi pribadinya; b) Pengungkapan fakta-fakta pribadi yang kurang pantas secara publik; c) Publisitas yang menempatkan kekeliruan seseorang di depan publik; d) Penguasaan tanpa izin atas kemiripan seseorang untuk keuntungan orang lain.

Eropa memberikan penekanan pada aspek perlindungan data pribadi yang sering disebut dengan "data", sebagai bagian dari perlindungan kehidupan pribadi. Definisi ini mengacu pada ketentuan Pasal 8 Konvensi Eropa yang memicu lahirnya berbagai penafsiran mengenai cakupan kehidupan pribadi, khususnya dalam sejumlah perkara, baik di European Court of Human Rights (ECtHR) atau Pengadilan HAM Eropa maupun di Court of Justice of the European Union (CJEU) atau Pengadilan Eropa. Ruang lingkup kehidupan pribadi menurut Pasal 8 Konvensi Eropa meliputi: akses ke data pribadi, intersepsi komunikasi, pilihan atau perubahan nama, kehidupan seksual, profesi atau domisili, perlindungan terhadap gangguan lingkungan, serta hak untuk membangun dan

\footnotetext{
19 J. Lee. Cardi, J. Lee Riccardi, "The German Federal Data Protection Act of 1977: Protecting the Right to privacy?", Boston College International and Comparative Law Review, Volume 6| Issue 1, (1983), hlm. 243.

20 William L. Prosser, "Privacy: a Legal Analysis", California Law Review 48, (1960), hlm. 338-423.
} 
mengembangkan hubungan dengan pihak lain. ${ }^{21}$

\section{International Covenant on Civil and} Political Rights (ICCPR) yang diratifikasi Indonesia melalui disahkannya UU Nomor 12 tahun 2005 sejauh ini masih menjadi rujukan utama yang dikutip banyak ahli terkait dengan hak atas privasi. Pada tahun 2016, Dewan Umum PBB telah mengadopsi perubahan atas hak atas privasi di era digital yang secar eksplisit dan langsung mengkonstruksikan bahwa pengintaian massal dan diskriminasi sebagai sebuah bentuk pelanggaran Pasal 17 ICCPR dan Pasal 12 Piagam Hak Asasi Manusia. Sebelumnya pada tahun 2014, Human Rights Commision membuat laporan terkait hak atas privasi di era digital sebagai bentuk respons atas permohonan Dewan Umum PBB dalam Resolusi 68/167. ${ }^{22}$ Pasal 17 ICCPR dam Pasal 12 Piagam Hak Asasi Manusia mengatur bahwa tidak seorangpun dapat secara sewenangwenang dan secara tidak sah dicampuri urusan-urusan pribadinya, keluarga, rumah, atau hubungan surat menyurat atau secara tidak sah diserang kehormatan dan atau nama baiknya. Setiap orang juga berhak atas perlindungan hukum terhadap gangguan dan pelanggaran sebagaimana disebutkan. ${ }^{23}$

Uni Eropa telah menerapkan regulasi perlindungan data sejak 1995 yang memberikan jaminan perlindungan efektif terhadap hak mendasar dalam perlindungan data. Permasalahan timbul ketika negara- negara anggota Uni Eropa menerapkan regulasi tersebut secara berbeda yang mengakibatkan adanya inkonsistensi, ketidakpastian hukum, serta munculnya kompleksitas. Sehingga diperlukan seperangkat aturan yang kuat untuk dapat memastikan hak orang atas perlindungan data pribadi. ${ }^{24}$ Modernasi regulasi juga diperlukan mengingat adanya fenomena perkembangan jejaring sosial, cloud computing, layanan berbasis lokasi seperti google maps, dan smart card memungkinkan pemrosesan data pribadi tumbuh secara eksponensial. Badan Legislatif Uni Eropa kemudian menerbitkan European Union General Data Protection Regulation (peraturan perlindungan data umum, selanjutnya disebut EU GDPR) yang berlaku sejak 25 Mei 2018.

Kerangka kerja EU GDPR tidak harus ditransformasikan ke dalam Undang-Undang domestik tiap negara tetapi harus secara langsung berlaku negara-negara anggota Uni Eropa. Klausul pembuka diberikan untuk memberikan diskresi kepada negaranegara anggota Uni Eropa untuk dapat memperkenalkan ketentuan domestik tambahan sebagai wujud konkretisasi serta implementasi EU GDPR untuk permasalahan yang spesifik di masing-masing negara. Parlemen Uni Eropa dan Konsil Eropa telah mencapai kesepakatan mengenai reformasi perlindungan data yang diusulkan oleh komisi. Reformasi ini merupakan langkah 
penting untuk memperkuat hak-hak dasar warga negara di era digital dan memfasilitasi perusahaan melalui simplifikasi regulasi untuk perusahaan di pasar digital tunggal (digital single market). Selama masa tahun 1960-an, sektor publik dan privat telah mempertimbangkan bahwa pemrosesan data secara otomatis dilakukan untuk efisiensi. ${ }^{25}$

Pasal 1 EU GDPR terdiri dari tiga ayat yang mengatur perlindungan perlindungan dalam pemrosesan data pribadi dan aturan terkait perpindahan data pribadi tersebut. $E U$ GDPR melindungi hak fundamental dan kebebasan manusia dan secara khusus hak atas perlindungan data pribadi. Kebebasan pergerakan data dalam negara Uni Eropa seharusnya dibatasi oleh perlindungan data pribadi. $^{26}$

Subjek perlindungan data pribadi hanya orang atau natural person bukan legal entity atau badan hukum. Hak perlindungan data pribadi berkembang dari hak untuk menghormati kehidupan pribadi atau the rights to private life. Sebuah konsep kehidupan pribadi manusia tentu saja berhubungan dengan manusia sebagai makhluk hidup. Individu adalah pemilik utama dari hak perlindungan data pribadi, sehingga pemilik data pribadi harus dapat memutuskan apakah data yang dimilikinya ingin dibagikan atau tidak, siapa saja yang dapat mengakses, apakah mungkin memodifikasi data informasi, dan lain-lain.

Data pribadi mengacu pada EU GDPR merupakan "setiap informasi terkait sesorang ("subjek data") yang dapat mengenali atau dikenali, baik secara langsung atau tidak langsung, terutama dengan merujuk pada sebuah tanda pengenal seperti nama, nomor identitas, data lokasi, data pengenal daring atau pada satu faktor atau lebih tentang identitas fisik, psikologis, genetik, mental, ekonomi, atau sosial orang tersebut." 27 Pada umumnya data pribadi dapat dibedakan dari dua kategori: pertama, data pribadi bersifat umum seperti nama, alamat, alamat email, data lokasi, IP Address, web cookies; kedua, data pribadi yang bersifat spesifik (sensitif) seperti ras, etnis, agama, pandangan politik, orientasi seksual, genetik, biometrik, kondisi mental dan kejiwaan, dan catatan kriminal.

EU GDPR yang telah diadopsi setidaknya lebih dari 100 (seratus) negara di Uni Eropa memuat aspek-aspek berikut dalam struktur hukum perlindungan data :

a) Cakupan dan jangkauan dari perlindungan data, termasuk cakupan pengendali dan prosesor data dan jangkauan teritorial/ yurisdiksi;

b) Definisi dan jenis data pribadi;

c) Prinsip-prinsip perlindungan data, mencakup di dalamnya alasan pemrosesan data;

d) Kewajiban pengendali dan prosesor data;

e) Hak-hak dari pemilik data (data subject);

f) Pengawasan dan penegakan undangundang, yang umumnya dilengkapi dengan independent supervisory authority (data protection authority).

Hukum perlindungan data seharusnya berlaku untuk data otomatis dan pemrosesan data otomatis serta format yang terstruktur untuk menyimpan data manual filling

25 J. Lee Riccardi, Op.Cit, hlm. 246.

26 Pasal 1 European Union General Data Protection Regulation, https://gdpr-info.eu/art-1-gdpr/

27 Pasal 4 (1) European Union General Data Protection Regulation, https://gdpr-info.eu/art-4-gdpr/ 
system). Regulasi perlindungan data nantinya seharusnya mencakup segala pemrosesan data pada komputer, telepon, perangkat IoT, dan catatan kertas serta menjangkau lembaga publik baik pemerintah maupun swasta.

\section{b. Urgensi Regulasi Perlindungan Data Pribadi di Indonesia}

Konstitusi sebagai sumber hukum tertinggi dari segala peraturan perundang-undangan sejatinya telah memberikan perlindungan data pribadi. Hal ini bisa kita lihat pada amandemen keempat Undang-Undang Dasar 1945 yang dituangkan dalam pasalpasal tentang hak asasi manusia sebagai perwujudan jaminan atas perlindungan HAM pada Pasal 28, 28A sampai dengan Pasal 28J. Selanjutnya mengenai perlindungan hakhak pribadi warga negara diatur melalui norma dalam Pasal $28 \mathrm{G}$ ayat (1) UndangUndang Dasar Negara Republik Indonesia Tahun 1945, yang menyatakan bahwa "Setiap orang berhak atas perlindungan diri pribadi, keluarga, kehormatan, martabat, dan harta benda yang di bawah kekuasaannya, serta berhak atas rasa aman dan perlindungan dari ancaman ketakutan untuk berbuat atau tidak berbuat sesuatu yang merupakan hak asasi." Namun demikian, norma tersebut tentu perlu dioperasionalisasikan ke dalam undangundang organik dan peraturan perundanganundangan yang terkait dengan perlindungan data menyesuaikan dengan hierarki peraturan perundang-undangan. ${ }^{28}$

Perkembangan teknologi di era revolusi industri 4.0 yang mengakibatkan eskalasi penyebaran informasi pribadi dalam berbagai bentuk komunikasi dan interaksi sosial masyarakat tentu menuntut adanya kepedulian pemerintah untuk dapat mengesahkan peraturan perundangundangan terkait perlindungan data pribadi yang khusus dan spesifik. Mengingat norma perlindungan data pribadi yang ada saat ini masih tersebar dalam banyak regulasi dan belum mengakomodasi kebutuhan hukum masyarakat khususnya dalam menghadapi tantangan globalisasi dan tuntutan revolusi industri 4.0.

Roscoe Pound menyatakan: "Kant rationalized the law in these terms as a system of principles or universal rules, to be applied to human action, whereby the free will of the actor may co-exist along with the free will of everyone else. Hegel rationalized the law in these terms as a system of principles wherein and whereby the idea of liberty was realizing in human experience......" 29

Penulis mencoba memaknai pendapat tersebut sebagai hukum merupakan serangkaian norma perlindungan kepentingan rakyat seperti keadilan, kebebasan dalam menentukan pilihan, kebebasan berpendapat, perlakuan adil dan manusia, hak untuk memperoleh kesejahteraan dan pekerjaan yang layak, termasuk di dalamnya persamaan hak dalam penegakan hukum. Penyelenggaraan kekuasaan mengejawantahkan kewajiban dalam menjaga dan melindungi kehidupan manusia. Tetapi dalam hal ini, Indonesia belum dapat secara utuh memberikan perlindungan data pribadi

28 Pasal 15 ayat (1) Undang-Undang Nomor 12 tahun 2011 sebagaimana diubah dengan Undang-Undang Nomor 15 Tahun 2019 tentang Pembentukan Peraturan Perundang-undangan mengatur bahwa materi muatan mengenai ketentuan pidana hanya dapat dimuat dalam Undang-Undang, Perda Provinsi, atau Perda Kabupaten/Kota.

29 Roscoe Pound, An Introduction to the Philosophy of Law, (USA: Yale University Press, 1930), hlm. 68. 
karena tersebarnya diksi perlindungan privasi dalam berbagai macam regulasi.

Dalam bahasan ini, Penulis akan menguraikan beberapa perlindungan data pribadi yang sudah diatur dalam berbagai perundang-undangan, di antaranya:

a) Perlindungan hak pribadi warga negara dalam Undang-Undang Nomor 39 Tahun 1999 tentang Hak Asasi Manusia, seperti hak untuk mengembangkan diri bagi warga negara adalah hak untuk mencari, memperoleh, menyimpan, mengolah, dan menyampaikan informasi dengan menggunakan segala jenis sarana yang tersedia. ${ }^{30}$ Negara memberikan pengakuan akan hak setiap orang atas perlindungan diri pribadi, keluarga, kehormatan, martabat, dan hak miliknya. ${ }^{31}$ Warga negara juga dijamin dari rasa aman karena tempat kediaman siapapun tidak boleh diganggu, menginjak atau memasuki suatu pekarangan tempat kediaman atau memasuki rumah yang bertentangan dengan kehendak orang yang mendiaminya hanya diperbolehkan dalam hal-hal yang telah ditetapkan dengan Undang-Undang. ${ }^{32}$ Terkait dengan relasi komunikasi antar warga negara, negara mengatur bahwa kemerdekaan dan rahasia dalam hubungan surat menyurat termasuk hubungan komunikasi suratmenyurat termasuk hubungan komunikasi sarana elektronika tidak boleh diganggu, kecuali atas perintah hakim atau kekuasaan

lain yang sah dan sesuai dengan ketentuan peraturan perundang-undangan. ${ }^{33}$

b) Perlindungan data pribadi di era digital yang diakomodasi dalam Peraturan Menteri Komunikasi dan Informasi Nomor 20 Tahun 2016 tentang Perlindungan Data Pribadi memuat tiga kategori sistem elektronik yang diatur pemerintah: ${ }^{34}$ pertama, sistem elektronik strategis yang merupakan sistem elektronik berdampak serius terhadap kepentingan umum, pelayanan publik, kelancaran penyelenggaraan negara, atau pertahanan dan keamanan negara; kedua, sistem elektronik tinggi merupakan sistem elektronik yang berdampak terbatas pada kepentingan sektor dan atau daerah tertentu; ketiga, sistem elektronik rendah merupakan sistem elektronik yang tidak termasuk pada sistem elektronik strategis dan sistem elektronik tinggi.

Perlindungan data pribadi dalam sistem elektronik harus melandaskan pada penghormatan terhadap data pribadi sebagai privasi. Setiap pemilik data pribadi memiliki hak atas datanya dalam sistem elektronik, diantaranya berhak atas kerahasiaan data pribadi, hak untuk mengajukan pengaduan dalam rangka penyelesaian sengketa data pribadi atas adanya kegagalan perlindungan kerahasiaan data pribadi oleh penyelenggara sistem elektronik kepada Menteri, hak untuk memperoleh

\footnotetext{
Pasal 14 ayat (2) Undang-Undang Nomor 39 tahun 1999 tentang Hak Asasi Manusia.

Pasal 29 ayat (2) Undang-Undang Nomor 39 tahun 1999 tentang Hak Asasi Manusia.

Pasal 31 UU Nomor 39 tahun 1999 tentang Hak Asasi Manusia.

Pasal 32 UU Nomor 39 tahun 1999 tentang Hak Asasi Manusia.

Pasal 4 Peraturan Menteri Komunikasi dan Informasi Nomor 4 tahun 2016 tentang Sistem Manajemen Pengamanan Informasi.
} 
akses atau kesempatan untuk mengubah dan memperbarui data pribadi tanpa mengganggu sistem pengelolaan data pribadi, hak untuk memperoleh akses atau kesempatan untuk mendapatkan historis data pribadinya, hak untuk meminta pemusnahan data dalam sistem elektronik dan dikelola oleh penyelenggara sistem elektronik. ${ }^{35}$

c) Perlindungan terhadap data dan informasi publik yang dihimpun oleh badan publik diatur dalam Pasal 6 ayat (3) huruf (c) UU Nomor 14 Tahun 2008 tentang Keterbukaan Informasi Publik yang memberikan penegasan kepada badan publik untuk tidak memberikan informasi publik yang berkaitan dengan hak-hak pribadi seseorang. Selanjutnya dalam Pasal 17 huruf (g) dan (h) menyebutkan bahwa akta otentik yang bersifat pribadi serta kemauan atau wasiat seseorang serta informasi yang berkaitan dengan rahasia pribadi dinyatakan sebagai informasi yang dikecualikan. Informasi yang mengungkap rahasia pribadi tersebut berkaitan dengan riwayat dan kondisi anggota keluarga, kondisi keuangan, pendapatan dan rekening bank seseorang, pengobatan kesehatan fisik dan psikis seseorang, serta riwayat pendidikan. ${ }^{36}$

d) Terkait dengan keuangan dan perbankan, Undang-Undang Nomor 10 Tahun 1998 yang mengatur tentang permasalahan kerahasiaan bank (bank secrecy) berlandaskan prinsip kerahasiaan (confidential principle) yang mewajibkan bank untuk merahasiakan segala sesuatu yang berkaitan dengan data pribadi dan informasi nasabah baik tentang keadaan keuangan maupun informasi yang bersifat pribadi. ${ }^{37}$ Asas kerahasiaan dan kepercayaan sebagai landasan kinerja lembaga keuangan diterapkan pula dalam hubungan antara bank dengan pihak nasabah. Nasabah yang menggunakan produk bank lainnya harus memberikan data pribadi yang dianggap perlu kepada bank.

e) Perlindungan data pribadi di bidang ekonomi dan keuangan yang menjadi isu krusial setelah semakin berkembangnya financial technology di Indonesia diatur dalam beberapa Peraturan Otoritas Jasa Keuangan. Berdasarkan Peraturan OJK Nomor 13/POJK.02/2018 tentang Inovasi Keuangan Digital di Sektor Jasa Keuangan, penyelenggara bisnis Fintech wajib menjaga kerahasiaan, keutuhan, dan ketersediaan data pribadi, data transaksi, dan data keuangan yang dikelolanya sejak data diperoleh hingga data tersebut dimusnahkan. ${ }^{38}$ Syarat pemanfaatan data dan informasi pengguna antara lain: ${ }^{39}$ memperoleh persetujuan dari pengguna,

35 Pasal 26 Peraturan Menteri Komunikasi dan Informasi Nomor 20 tahun 2016 tentang Perlindungan Data Pribadi dalam Sistem Elektronik.

36 lihat pula Bab IV Peraturan Komisi Informasi Nomor 1 Tahun 2010 tentang Standar Layanan Informasi Publik (PerKIP Nomor 1 Tahun 2010).

37 Djoni S. Gazali dan Rachmadi Usman, Hukum Perbankan, (Jakarta: Sinar Grafika, 2010), hlm. 30.

38 Pasal 30 ayat (1) Peraturan Otoritas Jasa Keuangan Nomor 13/POJK.02/2018 tentang Inovasi Keuangan Digital di Sektor Jasa Keuangan.

39 Pasal 30 ayat (2) Peraturan Otoritas Jasa Keuangan Nomor 13/P0JK.02/2018tentang Inovasi Keuangan Digital di Sektor Jasa Keuangan. 
menyampaikan batasan pemanfaatan data dan informasi dari pengguna, menyampaikan setiap perubahan tujuan pemanfaatan data dan informasi kepada pengguna dalam hal terdapat perubahan tujuan pemanfaatan data dan informasi dan media dan metode yang digunakan dalam memperoleh data dan informasi terjamin kerahasiaan, keamanan serta keutuhannya.

f) Dalam konteks pertahanan dan keamanan, isu perlindungan data pribadi mendapatkan pengecualian dari aparat penegak hukum berdasarkan ketentuan peraturan perundang-undangan yang berlaku. Pengecualian ini dapat berupa profiling, pembukaan data-data pribadi seseorang, perekaman komunukasi pribadi, akses rekening seseorang, pengintaian, dan lain sebagainya. Pengecualian tersebut dapat ditemukan dalam sejumlah aturan misalnya: UU Nomor 8 Tahun 1981 tentang KUHAP, UU Nomor 31 Tahun 1999 tentang Pemberantasan Tindak Pidana Korupsi, UU Nomor 30 Tahun 2002 tentang KPK, UU Nomor 21 Tahun 2007 tentang Pemberantasan Tindak Pidana Perdagangan Orang, UU Nomor 8 Tahun 2010 tentang Pemberantasan Tindak Pidana Pencucian Uang, UU Nomor 17 Tahun 2011 tentang Intelijen Negara, UU No. 18 Tahun 2011 tentang Komisi Yudisial, UU Nomor 9 Tahun 2013 tentang Pencegahan dan Pemberantasan Tindak Pidana Pendanaan Terorisme.
Dari beberapa kajian tentang perlindungan data pribadi dalam peraturan perundangan di Indonesia, jelas sangat dibutuhkan perlindungan hukum terhadap perlindungan data pribadi. Antonio Fortin mengemukakan sebuah teori perlindungan hukum, bahwa pentingnya perlindungan internasional hak asasi manusia yang ditujukan secara langsung kepada masyarakat internasional. Perlindungan ini didasarkan kepada konvensi internasional, hukum kebiasaan internasional atau prinsip-prinsip umum hukum internasional yang bertunjuan dalam tindakan antisipatoris atau preventif, kuratif atau mitigasi, dan pemulihan atau kompensatoris". ${ }^{40}$

Sejalan dengan pemikiran Antonio tersebut, sudah saatnya Indonesia melakukan perluasan prinsip yurisdiksi ekstrateritorial dalam penerapan Undang-Undang Nomor 11 Tahun 2008 tentang Informasi dan Transaksi Elektronik. Sejalan pula dengan telah diadopsinya perlindungan data yang diterapkan Uni Eropa dalam GDPR, baik jika Indonesia mampu menganalisis lebih dalam instrumen-intrumen Uni Eropa misalnya EU Regulation Nomor 01-/2014 tentang Electronic Identification Authentication and Trust Services (EIDAS) yang memberikan suatu ide tentang bagaimana harmonisasi peraturan tentang identitas digital dan data personal dalam diwujudkan dalam komunikasi elektronik. ${ }^{41}$

Pertemuan G20 di Hamburg pada tahun 2017 menyepakati salah satu hal penting yakni

\footnotetext{
40 Sigit Riyanto, "Kajian Hukum Internasional tentang Pengaruh Kedaulatan Negara terhadap Perlindungan Pengungsi Internal", (ringkasan disertasi Program Pascasarjana Fakultas Hukum Universitas Gadjah Mada Yogyakarta, 2009), hlm. 16.

41 https://www.thejakartapost.com/academia/2019/01/02/gdpr-humanizing-cyberspace.html
} 
pentingnya perlindungan data pribadi dalam konteks pengembangan ekonomi digital. ${ }^{42}$ Hasil dari pertemuan tersebut yang kemudian mendasari Peta Jalan E-Commerce yang disahkan melalui Peraturan Presiden Nomor 74 Tahun 2017 tentang Peta Jalan Sistem Perdagangan Nasional Berbasis Elektronik Tahun 2017-2019, meskipun hingga tulisan ini disusun RUU Perlindungan Data Pribadi belum juga melampui tahap pembahasan di DPR.

Beberapa negara di ASEAN justru lebih dahulu menyusun aturan khusus terkait perlindungan pribadi, misalnya Singapura di tahun 2012, Malaysia pada 2010, Filipina pada 2012, dan Thailand pada 2019. Mulai berlakunya EU GDPR sejak 25 Mei 2018 yang berdampak besar bagi perusahaanperusahaan Indonesia di berbagai sektor termasuk transportasi, e-commerce, perhotelan, maupun sektor lainnya yang melakukan praktik pengumpulan data pribadi seharusnya menjadi pemantik yang dapat menyegerakan disahkannya regulasi perlindungan data pribadi. ${ }^{43}$

Pemerintah telah melakukan beberapa kali perubahan Rancangan Undang-Undang Perlindungan Data Pribadi (selanjutnya disebut sebagai RUU PDP). Data terakhir yang penulis dapatkan RUU PDP yang terakhir dirilis pada bulan Desember $2019^{44}$ terdiri dari 15 bab dan 72 pasal. RUU PDP ini mengatur mengenai Ketentuan Umum, Jenis Data
Pribadi, Hak Pemilik Data Pribadi, Pemrosesan Data Pribadi, Kewajiban Pengendali Data Pribadi dan Prosesor Data Pribadi dalam Pemrosesan Data Pribadi, Transfer Data Pribadi, Sanksi Administratif, Larangan dalam Penggunaan Data Pribadi, Pembentukan Pedoman Perilaku Pengendali Data Pribadi, Penyelesaian Sengketa dan Hukum Acara, Kerjasama Internasional, Peran Pemerintah dan Masyarakat, Ketentuan Pidana, Ketentuan Peralihan, dan Ketentuan Penutup.

Data pribadi menurut RUU PDP adalah "setiap data tentang seseorang baik yang teridentifikasi dan/atau dapat diidentifikasi secara tersendiri atau dikombinasi dengan informasi lainnya baik secara langsung maupun tidak langsung melalui tidak langsung melalui sistem elektronik dan/ atau nonelektronik." Berbeda dengan subyek perlindungan data pribadi yang diatur dalam EU GDPR definisi "orang" dalam RUU ini adalah orang perseorangan atau korporasi. RUU PDP membagi data pribadi yang bersifat umum dan spesifik, namun menghapus dua ayat yang ada dalam RUU PDP versi bulan April 2019 yaitu bahwa data pribadi yang bersifat spesifik sensitif dan perolehannya hanya atas persetujuan pemilik data kecuali ditentukan lain dimana pengungkapan secara tanpa hak dapat melanggar privasi pemilik data pribadi. Pasal 3 ayat (2) huruf $d$ menyebutkan agama sebagai salah satu data pribadi yang

42 lihat G20 Digital Economy Ministerial Declaration : Shaping Digitalisastion for an Interconnected World dalam http://www.g20.utoronto.ca/2017/170407-digitalization.html.

43 Wahyudi Djafar, "Hukum perlindungan data Pribadi di Indonesia: Lanskap, Urgensi, dan Kebutuhan Pembaruan", (artikel di laman Universitas Gadjah Mada), http://law.ugm.ac.id/wp-content/uploads/sites/1043/2019/08/ Hukum-Perlindungan-Data-Pribadi-di-Indonesia-Wahyudi-Djafar.pdf.

44 https://www.hukumonline.com/js/pdfjs/web/viewer.html?file=/pusatdata/viewfile/lt5e310497c4d63/ parent/lt561f74edf3260 lihat juga https://kominfo.go.id/content/detail/24620/raker-tingkat-i-pemerintahjelaskan-ruu-pdp-ke-komisi-i-dpr-ri/0/berita_satker 
bersifat umum. ${ }^{45}$ Dalam perspektif Penulis, agama seharusnya dikategorikan sebagai data pribadi yang bersifat spesifik karena menyangkut privasi dan tidak dapat diakses dan diinformasikan tanpa sepengetahuan atau seizin pemilik data.

Sebagaimana penerapan hukum perlindungan data pribadi di beberapa negara lain, penerapan RUU PDP ini juga mengikuti asas extra-teritorial jurisdiction sebagaimana dinormakan berlaku untuk setiap orang, badan publik, dan organisasi/institusi yang melakukan perbuatan hukum di dalam maupun luar wilayah Indonesia. ${ }^{46}$

Dalam perspektif ICT, The law, which is mainly a tool for implementing policy, does not exist in a vacuum. The legal framework for critical information infrastructure protection must be considered in the larger context of the business, social, and technical environment. ${ }^{47}$ Dengan artian hukum terutama sebagai bagian dari pengejawantahan suatu kebijakan tidak akan bisa berlaku dalam keadaan diam. Kerangka kerja hukum untuk perlindungan infrastruktur informasi yang saat ini sangat kritis seharusnya dipertimbangkan untuk dikembangkan dalam konteks yang lebih luas dalam bisnis, sosial, dan lingkungan teknisnya.

RUU PDP telah mengakomodasi the rights to be forgotten dengan pengecualian berlakunya perlindungan data pribadi yang berlaku untuk: ${ }^{48}$ kepentingan pertahanan dan keamanan nasional, kepentingan proses penegakan hukum, kepentingan umum dalam rangka penyelenggaraan negara, kepentingan pengawasan sektor jasa keuangan, moneter, sistem pembayaran, dan stabilitas sistem keuangan, atau agregat data yang pemrosesannya ditujukan guna kepentingan statistik dan penelitian ilmiah dalam rangka penyelenggaran negara. Bagaimanapun, RUU ini belum memuat lebih lanjut bagaimana mekanisme atau batasan-batasan dalam pengecualian terhadap perlindungan data pribadi tersebut.

RUU PDP belum mengatur terkait pembentukan lembaga yang berfungsi sebagai pengawas, regulator, dan pengendali (independent regulatory body) atau komisi pengawas perlindungan data pribadi. Tugas ini diberikan kepada pemerintah sesuai dengan sektornya di bawah koordinasi dengan Kementerian Komunikasi dan Informatika. Hal ini dapat dimaknai bahwa Kementerian Dalam Negeri akan mengawasi data pribadi yang terkait kependudukan, Kementerian Hukum dan HAM akan mengawasi data pribadi yang terkait dengan passport, visa dan data hukum lainnya, OJK akan mengawasi data pribadi terkait keuangan dan perbankan, dan seterusnya. Terdapat empat aspek penting yang perlu menjadi concern dalam UU PDP. Pertama, terkait data sovereignty dan keamanan data, serta data demi kepentingan keamanan negara. Kedua, terkait dengan data owner, pemilik data pribadi maupun data spesifik lainnya. Ketiga, data user yang memerlukan data yang akurat sehingga dapat diverifikasi dengan baik. Keempat,

\footnotetext{
$45 \quad$ Pasal 3 ayat (2) Rancangan Undang-Undang Perlindungan Data Pribadi, update Desember 2019.

46 Pasal 2 Rancangan Undang-Undang Perlindungan Data Pribadi, update Desember 2019.

47 Steward D Personick, Critical Information Infrastructure Protection and the Law, (Washington DC: National Academy of Engineering National Research Council, 2003).

48 Pasal 16 ayat (1) Rancangan Undang-Undang Perlindungan Data Pribadi versi Desember 2019.
} 
pengaturan lalu lintas data khususnya lintas negara (cross border data flow). ${ }^{49}$

Kebutuhan regulasi perlindungan data pribadi belum dapat sejalan dengan tumbuhnya kesadaran masyarakat dalam melindungi data pribadi masing-masing seperti terlihat unggahan di media sosial yang mengandung konten pribadi seperti location ataupun pribadi. Masyarakat seakan belum memahami kebijakan privasi dan syarat ketentuan layanan aplikasi dalam pengisian data pribadi pada penggunaan platform sistem elektronik (transportasi online, financial technology, e-commerce).

Oleh karena itu, RUU Perlindungan Data Pribadi ini ditujukan untuk menjamin hak warga negara atas perlindungan diri pribadi dan menumbuhkan kesadaran masyarakat serta menjamin pengakuan dan penghormatan atas pentingnya perlindungan data pribadi. Penulis berharap Rancangan Undang-Undang Perlindungan Data Pribadi yang saat ini sudah masuk dalam tahap pembahasan di Dewan Perwakilan Rakyat dapat mengakomodasi perlindungan data pribadi secara maksimal. Hal ini juga penting agar dapat menjadi dasar hukum yang matang dalam pelaksanaan perlindungan data pribadi di Indonesia yang lebih baik pada masa yang akan datang.

\section{Penutup}

Berdasarkan uraian diatas, dapat ditarik kesimpulan bahwa perlindungan data pribadi masih menjadi permasalahan dalam kehidupan bermasyarakat maupun bernegara dikarenakan belum tersedianya undang-undang perlindungan data pribadi. Pengaturan mengenai perlindungan data yang ada belum cukup efektif karena masih tersebar dalam beberapa pengaturan yang bersifat sektoral sehingga belum dapat memberikan perlindungan yang optimal. Indonesia belum siap bersaing dalam dunia industri 4.0 dikarenakan belum memiliki peraturan perundang-undangan yang secara khusus mengatur mengenai perlindungan data pribadi.

RUU Perlindungan Data Pribadi yang sedang dibahas saat ini adalah sebuah manifestasi dari perlindungan ataupun pengakuan hak-hak dasar setiap manusia. Harapannya peraturan perlindungan data pribadi ini untuk menjamin hak warga negara atas perlindungan diri pribadi dan menumbuhkan kesadaran masyarakat serta menjamin pengakuan dan penghormatan atas pentingnya perlindungan data pribadi. Pembuat Undang-Undang (pemerintah dan legislator) diharapkan dapat menyegerakan pengesahan RUU Perlindungan Data Pribadi dengan menambahkan beberapa poin sebagaimana dipaparkan dalam penjelasan kajian ini dan mengupayakan adanya sosialisasi untuk menumbuhkan awareness dari masyarakat dalam melindungi data pribadinya ketika melakukan interaksi sosial khususnya di dunia maya.

\section{Daftar Pustaka}

\section{Buku}

Djoni S. Gazali dan Rachmadi Usman, Hukum Perbankan, (Jakarta: Sinar Grafika, 2010). 
Peter Mahmud Marzuki, Penelitian Hukum (Jakarta: Kencana, 2011).

Roscoe Pound, An Introduction to the Philosophy of Law, (USA: Yale University Press, 1930).

Steward D. Personick, Critical Information Infrastructure Protection and the Law, (Washington DC: National Academy of Engineering National Research Council)

Wahyudi Djafar dan Asep Komarudin, Perlindungan Hak Atas Privasi di InternetBeberapa Penjelasan Kunci, (Jakarta: Elsam, 2014).

\section{Makalah/Artikel/Prosiding/Hasil Penelitian}

J. Lee Riccardi, The German Federal Data Protection Act of 1977: Protecting the Right to privacy?, Boston College International and Comparative Law Review, Volume 6| Issue 1, (1983).

Naskah Akademik Rancangan Undang-Undang Perlindungan Data Pribadi.

Sigit Riyanto, "Kajian Hukum Internasional tentang Pengaruh Kedaulatan Negara terhadap Perlindungan Pengungsi Internal" (ringkasan disertasi Program Pascasarjana Fakultas Hukum Universitas Gadjah Mada Yogyakarta, 2009).

William L. Prosser, "Privacy: a Legal Analysis", California Law Review 48, (1960).

\section{Internet}

Benjamin G. Waters, "an International Rights to Privacy: Israeli intelligence Collection in the Occupied Palestinian Teritories", Georgetown Journal of International Law, Volume 50, (2019), lihat https://www.law.georgetown. edu/international-law-journal/wp-content/ uploads/sites/21/2019/10/GT-GJIL190033. pdf.

G20 Digital Economy Ministerial Declaration : Shaping Digitalisastion for an Interconnected World dalam http://www.g20.utoronto. ca/2017/170407-digitalization.html.

https://gdpr-info.eu/art-4-gdpr/

https://kominfo.go.id/content/detail/24039/ siaran-pers-no-15hmkominfo012020-tentangpresiden-serahkan-naskah-ruu-pdp-ke-dprri/0/siaran_pers https://kominfo.go.id/content/detail/24620/ raker-tingkat-i-pemerintah-jelaskan-ruu-pdpke-komisi-i-dpr-ri/0/berita_satker

https://www.csoonline.com/article/2130877/ data-breach/the-biggest-data-breaches-ofthe-21stcentury.html https://gdpr-info.eu/ art-1-gdpr/

https://www.hukumonline.com/js/pdfjs/web/ viewer.html?file=/pusatdata/viewfile / It5e310497c4d63/parent/lt561f74edf3260

https://www.ohchr.org/EN/UDHR/Pages/ Language.aspx? LangID=inz.

https://ww w.thejakartapost.com/ academia/2019/01/02/gdpr-humanizingcyberspace.html

Wahyudi Djafar, "Hukum perlindungan data Pribadi di Indonesia: Lanskap, Urgensi, dan Kebutuhan Pembaruan", (artikel di laman Universitas Gadjah Mada), http://law.ugm.ac.id/wpcontent/uploads/sites/1043/2019/08/ Hukum-Perlindungan-Data-Pribadi-diIndonesia-Wahyudi-Djafar.pdf.

\section{Peraturan}

Undang-Undang Dasar Negara Republik Indonesia Tahun 1945.

Undang-Undang Nomor 12 tahun 2011 sebagaimana diubah dengan Undang-Undang Nomor 15 Tahun 2019 tentang Pembentukan Peraturan Perundang-undangan.

Undang-Undang Nomor 39 tahun 1999 tentang Hak Asasi Manusia.

Undang-Undang Nomor 11 Tahun 2008 tentang Informasi dan Transaksi Elektronik.

Undang-Undang Nomor 19 Tahun 2016 tentang Informasi dan Transaksi Elektronik.

Peraturan Pemerintah Nomor 71 Tahun 2019 tentang Penyelenggaraan Sistem dan Transaksi.

Peraturan Komisi Informasi Nomor 1 Tahun 2010 tentang Standar Layanan Informasi Publik.

Peraturan Menteri Komunikasi dan Informasi Nomor 4 Tahun 2016 tentang Sistem Manajemen Pengamanan Informasi.

Peraturan Menteri Komunikasi dan Informasi Nomor 20 Tahun 2016 tentang Perlindungan Data Pribadi dalam Sistem Elektronik.

Peraturan Otoritas Jasa Keuangan Nomor 13/ POJK.02/2018 tentang Inovasi Keuangan Digital di Sektor Jasa Keuangan. 
Rancangan Undang-Undang Perlindungan Data Pribadi, update Desember 2019.

European Union General Data Protection Regulation.
Kovenan Internasional Hak Sipil dan Politik. Piagam Hak-Hak Fundamental Uni Eropa. 